\title{
Problems of Parents of Students with Learning Disabilities and Ordinary Students: A Comparative Study
}

\author{
Noor T. Al. Bdour ${ }^{1, *}$, Mohammad A. Beirat ${ }^{1} \&$ Murad A. Al-Bustanji ${ }^{1}$ \\ ${ }^{1} \mathrm{Al}$ - Hussein Bin Talal University, Jordan \\ *Corresponding author: E-mail: noorbdoor@ahu.edu.jo
}

Received: February 20, 2019 Accepted: March 15, 2019 Published: March 20, 2019

doi:10.5296/ije.v11i1.14378 URL: https://doi.org/10.5296/ije.v11i1.14378

\begin{abstract}
The study aimed at comparing the problems of parents with learning disabilities to the problems of parents of ordinary students, as well as studying the differences in the level of problems of parents of students with learning disabilities according to the variables of; student class, type of school, nature of the parents' relationship with the student, academic level of parent, monthly family income, number of family members. The study sample consisted of (140) parents of students with learning disabilities and (140) parents of ordinary students. Results indicated that the problems of the parents of students with learning disabilities are more statistically significant than the problems of parents of ordinary students in all dimensions and problems as a whole. The results also revealed that the problems related to the social aspect and the problems related to the school system and the problems as a whole among the parents of students with learning disabilities whose children study in public schools are statistically higher than the problems of parents who study in private schools. The results also indicate that the problems of parents of students with learning disabilities with lower monthly family income are statistically higher than the problems of parents with the highest monthly income within all dimensions and problems as a whole. Finally, the results showed that the problems related to the school system among the parents of students with learning disabilities with the largest family members were significantly higher than among parents with fewer family members.
\end{abstract}

Keywords: problems of parents, students with learning disabilities, ordinary students 


\section{Introduction}

Despite the increasing interest in the field of learning disabilities in terms of research and practicality, most of the attention was directed to students with learning disabilities, and their families did not receive such attention. There have been many studies and research that focused attention on the problems of students with learning disabilities and their needs, services and educational programs provided to them, but their families were not the focus of interest of researchers as much as the focus on children with learning disabilities.

The impact and effectiveness of parents of children with disabilities has evolved throughout history. Where parents established institutions, schools and supported the enactment of legislation on persons with disabilities, particularly recently. Parents from different cultural and economic backgrounds also used their skills and material and human resources to play a major role in learning disabilities field, starting with the establishment of private schools and securing financial grants to volunteer in public school programs (Mercer, 1997).

It is worth mentioning that the family is considered a key member of any educational team that provides services to any students with disabilities in general, in accordance with the laws and regulations (Hallahan, Kauffman, \& Pullen, 2012). There is no doubt that the family plays an important role in the education and education of its disabled child, and it has an important role in all stages, from the stage of detection, identification and diagnosis through planning and implementation to the evaluation of the programs presented to her child. (Hallahan, Kauffman, Pullen,2012; McNamara, 1985). Although there are laws and regulations that protect parents' rights to participate in their child's programs, principals do not treat parents as active partners (Cavendish, Harry, Menda, Espinosa, \& Mahotier, 2016; Valle, 2009). Parents of disabled students often complain that there are limits to their participation in the individualized educational plan (IEP), including their limited opportunities to make suggestions (Tucker \& Schwartz, 2013; Zeitlin \& Curcic, 2014).

Note that to make good decisions in the interests of children with learning disabilities, there should be a real partnership between parents and school. Both the school and parents are partners in decision making for students with learning disabilities (Landmark, Robert, \& Zhang, 2013).

It should also be noted that the role of the family depends not only on the participation of parents, but also on the participation of brothers and sisters and friends, including the extended family, and the need to include them all in service programs for children with disabilities. Successful communication between professionals and parents is one of the most important factors contributing to the success of educational programs for people with disabilities, including those with learning disabilities (Hallahan, Kauffman, \& Pullen, 2012). Al-Ayed (2003) noted that encouraging communication between the resource room teacher and the parents of students with learning disabilities is a priority in the process of developing the work in the resource rooms as one of the programs that serve these students. His study aimed to know the problems facing the resource room teachers in Jordan, whose results showed that problems related to the parents of students and the outside community were at the forefront of these teachers' problems. These problems have been reflected in the expectations of parents of 
students with learning disabilities for rapid results from the result of their child's enrollment in the resource room programs, their lack of cooperation with the school and the denial of their child's problem. Hadidi (2003) showed that there were problems with resource room teachers, was related to the parents of students with learning disabilities. Studies have shown that parents' involvement in educational activities helps improve their relationship with teachers, increases their understanding of special education, and increases their knowledge about the academic progress of their children, as well as the clear objectives of programs for their children (Gallagher \& Desimone, 1995).

Neitzal \& Stright (2004) confirm that a mother who had a high awareness of her participation in programs for her child with learning disabilities was more effective and successful than a mother who was not aware of her child's needs. Siebes et al. (2006) note that parents participate in all phases of their child's rehabilitation and that their satisfaction with the services provided to their children is high.

Studies show that parents suffer more psychological stress than other parents (Fredler, Simpson, $\&$ Clark, 2007). The family of the disabled child faces special problems and challenges in addition to those of the ordinary child's family. Disability often leads to psychological, economic, social and educational problems (Featherstone, 1980). The presence of a child with learning disabilities may affect all individuals in the family. It is noted that families with a learning disability are more likely to divorce than families of ordinary individuals (Wright, Matlock, \& Matlock, 1985). Therefore, parents of individuals with learning disabilities need greater support to enable them to be cohesive and accept the individual's condition. To support parents' adaptation to learning disabilities, Mercer (1997) mentions conditions that support the parent-teacher relationship, including:

1 - The presence of legislation that emphasizes the need for the participation of parents in the learning process

2. Continue the efforts of the parents to ensure the continuation of special programs and the promulgation of new legislation

3 - Document the role of positive and distinctive parents.

4 - Explain the impact of individuals with disabilities on parents and make it more understandable.

5. Provide books, materials and trainers to help parents understand and train children with learning disabilities.

6 - Making the responsibility of detection and identification of disability on the parents before entering the school.

7 - Recognizing that parents need the teacher to understand the educational needs of the child, as well as the teacher needs to parent to understand the emotional and psychological needs of the child.

Barsch (1969) argues that no parents are prepared to be a father of a child with learning 
disabilities, so specialists should focus on the learning skill of parents. The community provides multiple services to parents of ordinary children such as physical services, teachers, counsellors, babysitters, multiple programs and friends. While these services are not available to parents of children with learning disabilities. Parents of children with disabilities need support to help them adapt and to understand their responses to disability. Parents' reaction is grief, trauma, denial, blame and guilt, anger and grief. The reaction varies from one parent to another and must be supported by these reactions. Mercer (1997) mentions the steps of adapting parents with learning disabilities as follows:

1 -Awareness of the problem

2 - Realize the problem

3 - Look for the reasons

4 - Look for a cure

5. Accept the child's disabilities.

Dmbinski \& Mauser (1977) conducted a survey study for parents in the Association of children with learning disabilities to find out what the parents needs of the teacher, physiotherapist and psychologist. The study reached several things that should be done by the specialist, including:

1 - The language should be easy and free of terminology

2 - Emphasize the involvement of both parents with the child in meetings

3 - To provide the specialist books and reading materials that will help the parent to understand the child

4 - Send a copy of the child's status reports to the parents

5 - There should be cooperation between specialists in various specialties about the child

6 - Provide advice, administrative information and the process of learning periodically for parents

7 - Give feedback to parents about the academic performance and behaviour of the child

Lovitt and Cushing (1999) aimed to understand the perceptions of the parents of disabled youth about the services and programs offered to their children, the results of the study showed several obstacles and problems faced by parents. The most prominent were problems related to mobility, dialogue with specialists, Lack of understanding of the school system, and the sense of dissatisfaction and confusion surrounding the obstruction of their children.

Chang and Hsu (2007) aimed at understanding the perceptions of families in Taiwan about children with learning disabilities, the study showed that there are a range of family pressures faced by parents related to the economic, educational and physical aspects resulting from the disabilities experienced by their children.

Harwood (2007) discussed the role, nature, and consequences of families with severe learning 
disabilities for their children and described them at the end of life. The study also dealt with the nature of the students. He found that denial of families to the disorder of severe learning disabilities may hinder understanding and create many problems and tried to find practical ways to help families to get rid of regret and sorrow at present and in the future using a set of strategies. It was also found that working with students with learning disabilities and their families is a positive experience and offers valuable opportunities for the growth of individuals, especially specialists of psychiatric students.

Dyson (2010) impacts on the unforeseen effects of children with learning disabilities in their families examined these effects on family life. The study sample consisted of (11) parents of students with learning disabilities who were aged (8-16) years. They participated in two separate interviews. The results showed that there is a wide range of influences for children with learning disabilities in their families. Family and parents' contradictions, negative reactions to relatives, disabilities of interaction with the school environment. Standard patterns of dealing with families were discussed. It concluded with recommendations suggesting that families and students with learning disabilities should be supported.

Emam and Serei (2014) also discussed the role of the family in anticipating self-concept and self-esteem for ordinary students and students at risk of learning disabilities in Oman by excluding gender and parental education. A total of 259 primary school students were selected from the Muscat capital schools, 78 of whom were students at risk of learning disabilities, and 181 students were students using a scale. The results showed that the role and contribution of families was very strong after the self-concept of students at risk of learning disabilities and ordinary students, while the role of families and their contribution to the concept of self-esteem was weak for both groups of students and for all study variables, Family cohesion.

Showers and Kinsman (2017) aimed to identify the most important factors that contribute to the success of students with learning disabilities at the university level. The factors related to the background of the family, the contributions of the students and the success of the university were investigated. The sample consisted of 346 students with learning disabilities who joined the university in the years 2004-2012. The information was obtained from their official files in a longitudinal study. The results showed that the family background had a strong and direct impact on student contributions and success at the university. Students with families with a higher socioeconomic level had stronger educational records and had better chances of success at the university. However, these factors only account for $13 \%$ of the difference factors, which leads to the search for other important factors affecting the students' expectations for success.

However, the studies that dealt with the problem of parents of students with learning disabilities are almost limited, and they differed in their concerns. It emerged to the researchers that some of them were concerned with problems related to social and psychological aspects, and other studies dealt with economic problems, as well as studies concerned with the problems associated with Family and school. Therefore, this study was designed to identify the problems of parents with learning disabilities in different dimensions compared with the problems of parents of ordinary students, as well as study differences in the problems of parents of students with learning disabilities according to different variables. 


\section{A. Study Problem and Questions:}

Despite the increasing interest in special educational services and programs offered to students with special needs in general, and those with learning disabilities in particular at recent times. Despite the great development in legislation, laws, regulations and educational programs for students with learning disabilities, parents of students with special needs Including those with learning disabilities, have not received adequate and appropriate attention from researchers in the field of special education, as well as the limited programs and services directed to them, although the various laws and regulations made them a key member of the educational team and gave them rights and the important roles in the various stages associated with education and rehabilitation of children with special needs, and it is worth mentioning that there are many questions raised about the parents of students with learning disabilities and their problems, and this is what the current study will try to achieve. Specifically, the present study will attempt to answer the following questions:

1- Are the problems of parents of students with learning disabilities differ from those of ordinary students?

2-Are the problems of parents of students with learning disabilities differ according to the student's grade, type of school, relationship with the student, academic level of parent, average of monthly family income or number of family members?

\section{B. Importance of the Study}

Importance of the current study is that its results will reveal to us the problems of the parents of students with learning disabilities compared to the problems of the parents of ordinary students, which will help interested in this category of specialists, researchers and decision makers to identify this in order to improve the level of services provided to this class of students and their parent and provide therapeutic and preventive programs that contribute to reducing these problems, in order to enable families to make them more effective in dealing with their children with learning disabilities.

\section{Definition of Terms}

Students with Learning disabilities: Those students who were classified as having learning disabilities in the resource rooms in Amman, Jordan based on their classification.

Ordinary students: Those students who were enrolled in regular public schools in Amman and don't have any disabilities.

\section{Methodology}

\subsection{Study Sample}

Research community consists of all parents of students with learning disabilities enrolled in the resource rooms in Qweismeh district -south of Amman- for the academic year 2017/2018, estimated to be about 700 students in 28 public and private schools. 


\section{MlMacrothink}

International Journal of Education

ISSN 1948-5476

2019, Vol. 11, No. 1

The study was conducted on a sample of parents of students with learning disabilities, who were randomly selected from all parents of students with learning disabilities enrolled in the resource rooms in the regular government and private schools in Qweismeh. Another sample was chosen from the parents of ordinary students, who consisted of (140) students who were tested in a simple random way among the schools in which students with learning disabilities were present. Sample selection was divided into the variables of the study (child's grade, type of school, relationship with the student, academic level of the parent, average of monthly family income and number of family members). Table (1) shows the distribution of the sample according to study variables.

Table 1. Sample's Demographic Information

\begin{tabular}{|c|c|c|c|c|c|}
\hline \multicolumn{2}{|c|}{ Demographic variables } & \multicolumn{2}{|c|}{$\begin{array}{c}\text { Parents of students } \\
\text { with learning } \\
\text { disabilities }\end{array}$} & \multicolumn{2}{|c|}{$\begin{array}{l}\text { Parents of } \\
\text { ordinary } \\
\text { students }\end{array}$} \\
\hline & & $\mathrm{N}$ & $\%$ & $\mathrm{~N}$ & $\%$ \\
\hline \multirow[t]{2}{*}{ student class } & Second and third & 48 & 34.3 & 48 & 34.3 \\
\hline & Fourth, fifth and sixth & 92 & 65.7 & 92 & 65.7 \\
\hline \multirow{2}{*}{ school Type } & Private and voluntary & 77 & 55.0 & 77 & 55.0 \\
\hline & public & 63 & 45.0 & 63 & 45.0 \\
\hline relationship with & father & 85 & 60.7 & 87 & 62.1 \\
\hline the student & mother & 55 & 39.3 & 53 & 37.9 \\
\hline academic level & Basic & 73 & 52.1 & 25 & 17.9 \\
\hline \multirow[t]{2}{*}{ of the parent } & Secondary & 47 & 33.6 & 50 & 35.7 \\
\hline & $\begin{array}{l}\text { Diploma of } \\
\text { Community College } \\
\text { and above }\end{array}$ & 20 & 14.3 & 65 & 46.4 \\
\hline average of & Less than 500 dinars & 76 & 54.3 & 24 & 17.1 \\
\hline $\begin{array}{l}\text { monthly family } \\
\text { income }\end{array}$ & 500 dinars and more & 64 & 45.7 & 116 & 82.9 \\
\hline number of & Less than five & 22 & 15.7 & 28 & 20.0 \\
\hline family members & Five and more & 118 & 84.3 & 112 & 80.0 \\
\hline Total & & 140 & 100 & 140 & 100 \\
\hline
\end{tabular}

\subsection{Instrumentation}

In order to achieve the objectives of the present study, a tool was developed to identify parents' problems through a survey of previous literature related to the subject of the study, in order to derive the dimensions and items expressing the problems of parents of students with learning disabilities. It reached (54) Items divided into six dimensions, which formed the tool in its initial form. It was then presented to (4) arbitrators with specializations in the field of special education and psychological measurement, where the arbitrators recommended the following amendments: Clarification of a number of items, the deletion of items (4), and the amendment 
of the wording of some items in terms of language.

After that, the amendments recommended by the arbitrators were made, and the final form of the tool is a scale consisting of (50) items divided into six dimensions, corresponding to a scale of five grades: Strongly Agree, Agree, Neutral, Disagree, and Strongly Disagree. The dimensions have become as follows:

- Problems related to student and were in 10 items. It dealt with problems arising from the personality characteristics of the child with learning disabilities such as arrogance, rush, lack of attention and the resulting problems for parents.

- Problems related to the family aspect and was in 8 items. It dealt with family problems may result from the presence of a child with learning disabilities within the family, such as family disintegration, problems that may occur with brothers and sisters, and family chaos.

- Problems related to the social aspect and was in 8 items. Dealt with problems arising from the interaction of the child with learning disabilities with the community, and the associated social acceptance or rejection and social problems.

- Problems related to the economic aspect and was in 6 items. The financial and economic problems and the additional financial burdens resulting from the presence of a child with learning disabilities within the family regarding the costs and expenses of education and rehabilitation.

- Problems related to the psychological side and was in 8 items. Paragraphs dealing with psychological problems that may result from the presence of a child with learning disabilities within the family, such as anxiety, anger, depression and others

- Problems related to the school system and was in 10 items. The problems related to the school programs that are offered to students with learning disabilities and the problems related to family participation and communication between the family and the school, and what is provided to parents from the services of specialists and teachers.

Finally, the final form of the scale was presented to the competent arbitrators, who agreed that the scale should be finalized for the purposes of the current study.

\subsection{Reliability and Validity Study Tool}

Regarding the validity of the study instrument, it was achieved through the preparation procedures, which achieved the logical or content validity represented by the representation of the tool for the area of behavior to be measured and defined by the main dimensions mentioned earlier. Where the arbitrators unanimously agreed on the appropriateness of the items to the dimensions measured by an agreement of more than $90 \%$

Reliability of the study tool was obtained in the internal reliability method, using the Cronbach Alpha equation, and the total reliability coefficient (0.970), while the reliability coefficients on the main dimensions ranged between (0.843) and (0.933). Table (2) shows the values of reliability coefficients obtained using the Cronbach's Alpha equation for each dimension as well as the total reliability 


\section{Ml Macrothink}

Table 2. Determination of Reliability Coefficients Using the Cronbach Alpha Equation

\begin{tabular}{lc}
\hline Dimension & Reliability coefficients \\
\hline Problems related to the student & 0.882 \\
Problems related to the family aspect & 0.843 \\
Problems related to the social aspect & 0.873 \\
Problems related to the economic aspect & 0.858 \\
Problems related to the psychological side & 0.921 \\
Problems related to the school system & 0.933 \\
Overall & 0.970 \\
\hline
\end{tabular}

Given the overall reliability of the scale, it is found to be of relatively high value that makes it a reliable tool for the purposes of the study

\subsection{Application Procedures}

After finalizing the study tool, a special message was developed clarifying the purpose and objectives of the study. The respondent will be reassured about the confidentiality of the information to be presented and explain how to answer the tool. The researchers also obtained official approvals, as well as the data for the source rooms representing the study population. The study sample was then randomly selected. After that, the parents who showed the sample of the study were interviewed and applied to the tool, after the purpose of the study was clarified. The data collection process took about two months. After the completion of the data collection was discharged and the work of the appropriate statistical analysis

\subsection{Extracting Degrees}

After the application was applied to the study sample, a score was given to each item. The fiveword verbal answer scale was translated into a numerical scale by giving the answer class (strongly agree) five grades, (I agree) four grades (neutral) three grades, (Disagree) two degrees, and class (strongly disagree) one grade.

\subsection{Statistical Processing}

To answer the first question, parents' mean scores were extracted on each dimension and on the scale as a whole in terms of the answer scale, and then the ( $\mathrm{T}$ - test) was used for the independent samples to indicate differences between the averages. To answer the second question, (A student's grade, school type, average of family monthly income, number of family members) One Way Anova was used, followed by the least significant differences (LSD) test for the remote comparisons in the case of differences depending on variables containing more than one level as (Academic level of parent).

\section{Results and Discussion}

Present study aimed at identifying the problems of parents of students with learning disabilities compared to the problems of parents of ordinary students, as well as studying the differences 
in the level of problems of parents of students with learning disabilities according to the variables of student's grade, type of school, parent's academic level, relationship with the student, average of monthly family income, and number of family members.

To answer the first question: Are the problems of parents of students with learning disabilities differ from those of ordinary students? Parents' scores were extracted on each dimension and on the scale as a whole in terms of the answer scale. Thus, the (T-test) was used for the independent samples to indicate the differences between the means. Table (3) shows this.

Table 3. Parent and Dimensions (M) Means, and (T) Scores

\begin{tabular}{|c|c|c|c|c|}
\hline Dimension & parents & $\mathrm{M}$ & $\mathrm{T}$ & Sig. \\
\hline \multirow{2}{*}{$\begin{array}{l}\text { problems related to the } \\
\text { student }\end{array}$} & ordinary students' parents & 2.3847 & $11.115^{*}$ & .000 \\
\hline & $\begin{array}{l}\text { students with learning } \\
\text { disabilities parents }\end{array}$ & 3.3949 & & \\
\hline \multirow{2}{*}{$\begin{array}{l}\text { Problems related to the } \\
\text { family aspect }\end{array}$} & ordinary students' parent & 2.2972 & $7.572 *$ & .000 \\
\hline & $\begin{array}{l}\text { students with learning } \\
\text { disabilities parents }\end{array}$ & 2.9965 & & \\
\hline \multirow{2}{*}{$\begin{array}{l}\text { Problems related to the } \\
\text { social aspect }\end{array}$} & ordinary students' parent & 2.0659 & $9.571 *$ & .000 \\
\hline & $\begin{array}{l}\text { students with learning } \\
\text { disabilities parents }\end{array}$ & 3.0268 & & \\
\hline \multirow{2}{*}{$\begin{array}{l}\text { Problems related to the } \\
\text { economic aspect }\end{array}$} & ordinary students' parent & 2.6724 & $6.376^{*}$ & .000 \\
\hline & $\begin{array}{l}\text { students with learning } \\
\text { disabilities parents }\end{array}$ & 3.4290 & & \\
\hline \multirow{2}{*}{$\begin{array}{l}\text { Problems related to the } \\
\text { psychological aspect }\end{array}$} & ordinary students' parent & 1.7333 & $7.440 *$ & .000 \\
\hline & $\begin{array}{l}\text { students with learning } \\
\text { disabilities parents }\end{array}$ & 2.5207 & & \\
\hline \multirow{2}{*}{$\begin{array}{l}\text { Problems related to the } \\
\text { school system }\end{array}$} & ordinary students' parent & 2.4326 & $8.631^{*}$ & .000 \\
\hline & $\begin{array}{l}\text { students with learning } \\
\text { disabilities parents }\end{array}$ & 3.3986 & & \\
\hline \multirow[t]{2}{*}{ Overall } & ordinary students' parent & 2.2583 & $10.576^{*}$ & .000 \\
\hline & $\begin{array}{l}\text { students with learning } \\
\text { disabilities parents }\end{array}$ & 3.1377 & & \\
\hline
\end{tabular}

*Sig. at $\alpha \leq 0.05$

Table (3) shows that there are statistically significant $(\alpha \leq 0.05)$ between the problems of parents with learning and the problems of parents of ordinary students in all dimensions and problems, as the average showed that the problems of parents of students with learning disabilities are more than the problems of parents of ordinary students in all dimensions and problems as a whole. These results are consistent with the educational literature which indicates that the families of students with disabilities generally face additional special problems posed by the nature of the disability, since families are usually prepared and equipped to deal with ordinary children. The society with its various social, educational and economic institutions is 


\section{Macrothink}

International Journal of Education

ISSN 1948-5476

2019, Vol. 11, No. 1

often more suitable for ordinary students which making the families of students with disabilities more vulnerable than the families of ordinary students (Barsch, 1969; Featherstone, 1980; Hallahan, Kauffman, Pullen, 2012; Mercer, 1997).

To answer the second question: Are the problems of parents of students with learning disabilities differ according to the student's grade, type of school, the relationship with the student, academic level of parent, average of monthly family income or number of family members? The (T-test) of independent samples was used to denote differences between means in the case of two-level variables (student class, school type, relationship with students, average of monthly family income, number of family members). One Way Anova was used followed by the least significant differences test (LSD) for significant differences in the case of differences depending on variables containing more than two levels as (the academic level of the parent). Tables $(4,5,6,7,8$, and 9$)$ shows this.

Table 4. T-test Results for Independent Samples to Indicate the Differences between the Means According to the Student's Class Variable

\begin{tabular}{lllll}
\hline Dimension & class & M & T & Sig. \\
\hline problems related to the & Second, third & 3.4671 & .836 & .405 \\
student & Fourth, fifth, sixth & 3.3572 & & \\
Problems related to the & Second, third & 3.1223 & 1.319 & .189 \\
family aspect & Fourth, fifth, sixth & 2.9309 & & \\
Problems related to the & Second, third & 3.0772 & .473 & .637 \\
social aspect & Fourth, fifth, sixth & 3.0005 & & \\
Problems related to the & Second, third & 3.5715 & \multirow{2}{*}{1.256} & .211 \\
economic aspect & Fourth, fifth, sixth & 3.3547 & & \\
Problems related to the & Second, third & 2.6484 & \multirow{2}{*}{1.079} & .282 \\
psychological aspect & Fourth, fifth, sixth & 2.4541 & & \\
Problems related to the & Second, third & 3.4555 & .515 & .607 \\
school system & Fourth, fifth, sixth & 3.3688 & & \\
Overall & Second, third & 3.2293 & \multirow{2}{*}{1.072} & .286 \\
& Fourth, fifth, sixth & 3.0900 & & \\
\hline
\end{tabular}

*Sig. at $\alpha \leq 0.05$ 


\section{Macrothink}

International Journal of Education

ISSN 1948-5476

2019, Vol. 11, No. 1

Table 5. T-test Results for independent Samples to Indicate the Differences between the Means According to the School Type Variable

\begin{tabular}{|c|c|c|c|c|}
\hline Dimension & School type & $\mathrm{M}$ & $\mathrm{T}$ & Sig. \\
\hline \multirow{2}{*}{$\begin{array}{l}\text { problems related to the } \\
\text { student }\end{array}$} & Private and voluntary & 3.2925 & 1.833 & .069 \\
\hline & Public & 3.5201 & & \\
\hline \multirow{2}{*}{$\begin{array}{l}\text { Problems related to the } \\
\text { family aspect }\end{array}$} & Private and voluntary & 2.9032 & 1.500 & .136 \\
\hline & Public & 3.1105 & & \\
\hline \multirow{2}{*}{$\begin{array}{l}\text { Problems related to the } \\
\text { social aspect }\end{array}$} & Private and voluntary & 2.8673 & $2.332 *$ & .021 \\
\hline & Public & 3.2217 & & \\
\hline \multirow{2}{*}{$\begin{array}{l}\text { Problems related to the } \\
\text { economic aspect }\end{array}$} & Private and voluntary & 3.3766 & .705 & .482 \\
\hline & Public & 3.4931 & & \\
\hline \multirow{2}{*}{$\begin{array}{l}\text { Problems related to the } \\
\text { psychological aspect }\end{array}$} & Private and voluntary & 2.3814 & 1.815 & .072 \\
\hline & Public & 2.6909 & & \\
\hline \multirow{2}{*}{$\begin{array}{l}\text { Problems related to the } \\
\text { school system }\end{array}$} & Private and voluntary & 3.1385 & $3.776^{*}$ & .000 \\
\hline & Public & 3.7164 & & \\
\hline \multirow[t]{2}{*}{ Overall } & Private and voluntary & 2.9961 & $2.589 *$ & .011 \\
\hline & Public & 3.3108 & & \\
\hline
\end{tabular}

*Sig. at $\alpha \leq 0.05$

Table 6. T-test Results for Independent Samples to Indicate the Differences between the Means According to the Relationship with the Student Variable

\begin{tabular}{llllc}
\hline Dimension & $\begin{array}{l}\text { The relationship } \\
\text { with the student }\end{array}$ & & M & Sig. \\
& Father & 3.4561 & 1.223 & .224 \\
problems related to the & Mother & 3.3004 & & \\
student & Father & 3.0733 & 1.387 & .168 \\
Problems related to the & Mother & 2.8779 & & \\
family aspect & Father & 3.1083 & 1.323 & .188 \\
Problems related to the & Mother & 2.9008 & & \\
social aspect & Father & 3.4929 & .967 & .335 \\
Problems related to the & Mother & 3.3303 & & \\
economic aspect & Father & 2.6144 & 1.365 & .174 \\
Problems related to the & Mother & 2.3760 & & \\
psychological aspect & Father & 3.4766 & 1.219 & .225 \\
Problems related to the & Mother & 3.2780 & & \\
school system & Father & 3.2142 & 1.549 & .124 \\
Overall & Mother & 3.0195 & & \\
\hline
\end{tabular}

*Sig. at $\alpha \leq 0.05$ 
Table 7. T-test Results for Independent Samples to Indicate the Differences between the Means According to the Average of Monthly Family Income Variable

\begin{tabular}{|c|c|c|c|c|}
\hline Dimension & $\begin{array}{l}\text { Average of monthly } \\
\text { family income }\end{array}$ & M & $\mathrm{T}$ & Sig. \\
\hline \multirow{2}{*}{$\begin{array}{l}\text { problems related to the } \\
\text { student }\end{array}$} & Less than 500 dinars & 3.6144 & $4.046^{*}$ & .000 \\
\hline & 500 dinars and more & 3.1342 & & \\
\hline \multirow{2}{*}{$\begin{array}{l}\text { Problems related to the } \\
\text { family aspect }\end{array}$} & Less than 500 dinars & 3.1864 & $3.087^{*}$ & .002 \\
\hline & 500 dinars and more & 2.7710 & & \\
\hline \multirow{2}{*}{$\begin{array}{l}\text { Problems related to the } \\
\text { social aspect }\end{array}$} & Less than 500 dinars & 3.2752 & $3.682 *$ & .000 \\
\hline & 500 dinars and more & 2.7317 & & \\
\hline \multirow{2}{*}{$\begin{array}{l}\text { Problems related to the } \\
\text { economic aspect }\end{array}$} & Less than 500 dinars & 3.5877 & $2.133^{*}$ & .035 \\
\hline & 500 dinars and more & 3.2406 & & \\
\hline \multirow{2}{*}{$\begin{array}{l}\text { Problems related to the } \\
\text { psychological aspect }\end{array}$} & Less than 500 dinars & 2.7532 & $3.049 *$ & .003 \\
\hline & 500 dinars and more & 2.2446 & & \\
\hline \multirow{2}{*}{$\begin{array}{l}\text { Problems related to the } \\
\text { school system }\end{array}$} & Less than 500 dinars & 3.6280 & $3.244^{*}$ & .001 \\
\hline & 500 dinars and more & 3.1260 & & \\
\hline \multirow[t]{2}{*}{ Overall } & Less than 500 dinars & 3.3543 & $4.029 *$ & .000 \\
\hline & 500 dinars and more & 2.8805 & & \\
\hline
\end{tabular}

*Sig. at $\alpha \leq 0.05$

Table 8. T-test Results for Independent Samples to Indicate the Differences between the Means According to the Number of Family Members Variable

\begin{tabular}{|c|c|c|c|c|}
\hline Dimension & $\begin{array}{l}\text { number of family } \\
\text { members }\end{array}$ & $M$ & $\mathrm{~T}$ & Sig. \\
\hline \multirow{2}{*}{$\begin{array}{l}\text { problems related to the } \\
\text { student }\end{array}$} & Less than five & 3.2409 & 1.068 & .288 \\
\hline & Five and more & 3.4236 & & \\
\hline \multirow{2}{*}{$\begin{array}{l}\text { Problems related to the } \\
\text { family aspect }\end{array}$} & Less than five & 2.8239 & 1.080 & .282 \\
\hline & Five and more & 3.0287 & & \\
\hline \multirow{2}{*}{$\begin{array}{l}\text { Problems related to the } \\
\text { social aspect }\end{array}$} & Less than five & 2.8896 & .770 & .443 \\
\hline & Five and more & 3.0523 & & \\
\hline \multirow{2}{*}{$\begin{array}{l}\text { Problems related to the } \\
\text { economic aspect }\end{array}$} & Less than five & 3.1439 & 1.506 & .134 \\
\hline & Five and more & 3.4822 & & \\
\hline \multirow{2}{*}{$\begin{array}{l}\text { Problems related to the } \\
\text { psychological aspect }\end{array}$} & Less than five & 2.2443 & 1.400 & .164 \\
\hline & Five and more & 2.5722 & & \\
\hline \multirow{2}{*}{$\begin{array}{l}\text { Problems related to the } \\
\text { school system }\end{array}$} & Less than five & 2.9545 & $2.449 *$ & .016 \\
\hline & Five and more & 3.4813 & & \\
\hline \multirow[t]{2}{*}{ Overall } & Less than five & 2.8884 & 1.758 & .081 \\
\hline & Five and more & 3.1842 & & \\
\hline
\end{tabular}

*Sig. at $\alpha \leq 0.05$ 
Table 9. One-Way ANOVA Results Indicate the Differences between the Means According to the Academic Level of the Parent Variable

\begin{tabular}{lllllll}
\hline Dimension & $\begin{array}{l}\text { number of family } \\
\text { members }\end{array}$ & df & $\begin{array}{l}\text { Sum } \\
\text { square }\end{array}$ & $\begin{array}{l}\text { Mean } \\
\text { square }\end{array}$ & f & Sig. \\
\hline problems related to the & Between groups & 2 & 2.332 & 1.166 & 2.181 & .117 \\
& Within groups & 137 & 73.233 & .535 & & \\
student & Between groups & 2 & 3.187 & 1.594 & 2.435 & .091 \\
Problems related to the & Within groups & 137 & 89.654 & .654 & & \\
family aspect & Between groups & 2 & 2.521 & 1.260 & 1.539 & .218 \\
Problems related to the & Within groups & 137 & 112.214 & .819 & & \\
Problems related to the & Between groups & 2 & 3.294 & 1.647 & 1.764 & .175 \\
economic aspect & Within groups & 137 & 127.892 & .934 & & \\
Problems related to the & Between groups & 2 & 5.336 & 2.668 & 2.667 & .0 .730 \\
psychological aspect & Within groups & 137 & 137.037 & 1.000 & & \\
Problems related to the & Between groups & 2 & 1.664 & .832 & .935 & .395 \\
school system & Within groups & 137 & 121.881 & .890 & & \\
Overall & Between groups & 2 & 2.274 & 1.137 & 2.168 & .118 \\
& Within groups & & & & & \\
\hline
\end{tabular}

*Sig. at $\alpha \leq 0.05$

Table (4), Table (6), and Table (9) show that there are no statistically significant differences ( $\alpha$ $\leq 0.05$ ) in the mean of the problems of parents of students with learning disabilities within all dimensions depending on the variables of student class, nature of the relationship to the student, and academic level of the parent.

As shown in Table (5), there are statistically significant differences in the mean of the problems of the parents of students with learning disabilities in the social problems according to the school type variable $(\mathrm{T}=2.332 \alpha=0.021)$. The values showed that the mean of problems of parents whose children attend public schools (mean=3.2217) is higher than parents whose children attend private schools (mean $=2.8673$ ). There were also statistically significant differences in the field of problems related to the school system $(\mathrm{T}=3.766 \alpha=0.000)$. Parents whose children attended public schools $($ mean $=3.7164)$ were higher than parents whose children attended private schools (mean $=3.1385$ ). There were also statistically significant differences in the problems as a whole $(\mathrm{T}=2.589 \alpha=0.011)$. Parents whose children attended school in public schools (mean $=3.3108$ ) were higher than parents whose children attended private schools $($ mean $=2.9961)$, While there were no statistically significant differences $(\alpha \leq$ 0.05) in the means of the parents' problems in the other dimensions according to the school type variable. These results are consistent with the reality of public schools characterized by overcrowding and the large number of students per class, resulting in lack of follow-up and poor communication opportunities between parents and specialists in public schools, thus increasing their problems. Conversely, private schools are better in number per class, and communication and family participation are better than parents' problems. 
As shown in Table (7), there are statistically significant differences $(\alpha \leq 0.05)$ in the mean of problems of parents of students with learning disabilities within all dimensions and problems as a whole according to the variable of monthly family income. The values showed that the mean of problems of parents with the lowest monthly income (less than JD 500) were higher than those with higher monthly income (JD 500 and more). These findings are consistent with educational literature. Showers \& Kinsman (2017) noted that the family background has a strong and direct impact on students' contributions and success at the university, and students with families with higher social and economic levels had stronger educational records and had opportunities best in success at university. The presence of a child with learning disabilities within the family is also burdened with financial burdens and additional expenses, which increases the problems and suffering of low-income families.

As shown in Table (8), there are statistically significant differences in the mean of problems of parents of students with learning disabilities in the field of problems related to the school system according to the variable number of family members $(T=2.449 \alpha=0.016)$. The number of family members (five and above) (mean $=3.413$ ) is higher than that of parents with fewer family members (less than five) (mean $=2.9545$ ). There were no statistically significant differences $(\alpha \leq 0.05)$ in the average of parents' problems among the other dimensions according to the variable number of family members. This may be attributed to the fact that the increase in the number of family members reduces the chances of follow-up of students with learning disabilities by parents, and the percentage of family participation in programs offered to student's increases, thus increasing the problems of parents regarding to the school system

\section{Conclusion}

Recently the concern of learning disabilities field has increased both theoretically and practically, most studies concerned on students with learning disabilities, and there are few studies dealt with families of students with learning disabilities, despite the fact that all laws and regulations considered family as a key member of the educational team, also there is a general agreement between researchers and specialists on the significant role played by families in programs and services provided to their children. The current study focused on the problems faced by families of students with learning disabilities, and its results confirmed the educational literature, where the problems of the families of students with learning disabilities were higher than the problems of ordinary families in various fields such as problems related to student, family aspect, social problems, economic problems, psychological problems and school system. Some differences in the problems of families of students with learning disabilities also appeared in some variables, Such as the type of school, the average of monthly family income and the number of family members.

Considering the study results, the researchers recommend that:

1. Conduct further studies and research about the families of students with learning disabilities in general, and the subject of problems in particular

2. The need to pay attention to the design and implementation of support programs for parents 
of students with learning disabilities, especially cognitive, educational, psychological, social and economic support programs aimed at empowering families.

3. The need to activate family participation in the programs of students with learning disabilities and encourage the continuity of parents and their interaction with specialist.

\section{References}

Al-Ayed, W. (2003). Problems faced by elementary school resource room teachers. Unpublished Thesis, Amman Arab University, Amman, Jordan.

Barsch, R. H. (1969). The parent teacher partnership. Arlington, VA: Council for Exceptional Children.

Cavendish, W., Harry, B., Menda, A., Espinosa, A., \& Mahotiere, M. (2016). Implementing response to intervention: Challenges of diversity and system change in a high stakes environment. Teachers College Record, 118(050301), 1-36.

Chang, M. Y., \& Hsu, L. L. (2007). The perceptions of Taiwanese families who have children with learning disability. Journal of Clinical Nursing, 16(12), 2349-2356. https://doi.org/10.1111/j.1365-2702.2007.02013.x

Dembinski, R. J., \& Mauser, A. J. (1977). What parents of the learning disabled really want from professionals. Journal of Learning Disabilities, 10(9), 578-584. https://doi.org/10.1177/002221947701000907

Dyson, L. (2010). Unanticipated effects of children with learning disabilities on their families. Learning Disability Quarterly, 33(1), 43-55. https://doi.org/10.1177/073194871003300104

Emam, M. M., \& Abu-Serei, U. S. (2014). Family Functioning Predictors of Self-Concept and Self-Esteem in Children at Risk for Learning Disabilities in Oman: Exclusion of Parent and Gender Contribution. International Education Studies, 7(10), 89-99. https://doi.org/10.5539/ies.v7n10p89

Featherstone, H. (1980). A difference in the family: Living with a disabled child. New York: Penguin Books.

Fiedler, C. R., Simpson, R. L., \& Clark, D. M. (2007). Parents and families of children with disabilities: Effective school-based support services. Pearson Merrill/Prentice Hall.

Gallagher, J., \& Desimone, L. (1995). Lessons learned from implementation of the IEP: Applications to the IFSP. Topics in Early Childhood Special Education, 15(3), 353-378. https://doi.org/10.1177/027112149501500307

Hadidi, M. (2003). Problems faced by resource room teachers in Jordan. Special Education Academy Journal, 2, 1-40.

Hallahan, D. P., Kauffman, J. M., \& Pullen, P. C. (2012). Exceptional learners: Introduction 
to special education (12th ed.). Boston: Allyn and Bacon.

Harwood, I. (2007). A family facing end of life issues of a person with learning disabilities-a personal reflection. British Journal of Learning Disabilities, 35(2), 102-106. https://doi.org/10.1111/j.1468-3156.2007.00442.x

Landmark, L., Roberts, E., \& Zhang, D. (2013). Educators' beliefs and practices about parent involvement in transition planning. Career Development and Transition for Exceptional Individuals, 36, 114-123. https://doi.org/10.1177/2165143412463047

Lovitt, T. C., \& Cushing, S. (1999). Parents of youth with disabilities: Their perceptions of school programs. Remedial and Special Education, 20(3), 134-142. https://doi.org/10.1177/074193259902000303

McNamara, B. (1985). Teacher consultation: The key to a successful resource room program. Journal of Learning, 1(5), 120- 140.

Mercer, C. (1997). Students with Learning Disabilities (5th ed.). New Jersey: Prentice-Hall, Inc.

Neitzel, C., \& Dopkins Stright, A. (2004). Parenting behaviors during child problem solving: The roles of child temperament, mother education and personality, and the problemsolving context. International Journal of Behavioral Development, 28(2), 166-179. https://doi.org/10.1080/01650250344000370

Showers, A., \& Kinsman, J. (2017). Factors That Contribute to College Success for Students with Learning Disabilities. Learning Disability Quarterly, 40(2), 81-90. https://doi.org/10.1177/0731948717690115

Siebes, R. C., Wijnroks, L., Ketelaar, M., Van Schie, P. E., Gorter, J. W., \& Vermeer, A. (2007). Parent participation in pediatric rehabilitation treatment centers in the Netherlands: a parents' viewpoint. Child: care, health and development, 33(2), 196-205. https://doi.org/10.1111/j.1365-2214.2006.00636.x

Tucker, V., \& Schwartz, I. (2013). Parents' perspectives of collaboration with school professionals: Barriers and facilitators to successful partnerships in planning for students with ASD. School Mental Health, 5, 3-14. https://doi.org/10.1007/s12310-0129102-0

Valle, J. (2009). What mothers say about special education: From the 1960s to the present. London, England: Palgrave McMillan. https://doi.org/10.1057/9780230619739

Wright, L. S., Matlock, K. S., \& Matlock, D. T. (1985). Parents of Handicapped Children: Their Self-Ratings, Life Satisfaction and Parental Adequacy. The Exceptional Child, 32(1), 37-40. https://doi.org/10.1080/0156655850320106

Zeitlin, V., \& Curcic, S. (2014). Parental voices on Individualized Education Programs: “Oh, IEP meeting tomorrow? Rum tonight!” Disability \& Society, 29, 373-387. https://doi.org/10.1080/0 9687599.2013.77649 


\section{Macrothink}

\section{Copyright Disclaimer}

Copyright for this article is retained by the author(s), with first publication rights granted to the journal.

This is an open-access article distributed under the terms and conditions of the Creative Commons Attribution license (http://creativecommons.org/licenses/by/3.0/). 